OPEN ACCESS

Edited by:

Maria Jose Sousa-Gallagher, University College Cork, Ireland

Reviewed by: Robert David Hall,

Wageningen University and

Research, Netherlands

Rebogile Mphahlele,

Agricultural Research Council of South

Africa (ARC-SA), South Africa

*Correspondence:

Antonio Raffo

antonio.raffo@crea.gov.it orcid.org/0000-0002-8507-2374

Specialty section

This article was submitted to

Sustainable Food Processing, a section of the journal

Frontiers in Sustainable Food Systems

Received: 16 March 2021 Accepted: 30 November 2021

Published: 14 January 2022

Citation:

Raffo A and Paoletti F (2022) Fresh-Cut Vegetables Processing: Environmental Sustainability and Food Safety Issues in a Comprehensive

Perspective

Front. Sustain. Food Syst. 5:681459. doi: 10.3389/fsufs.2021.681459

\section{Fresh-Cut Vegetables Processing: Environmental Sustainability and Food Safety Issues in a Comprehensive Perspective}

\author{
Antonio Raffo * and Flavio Paoletti \\ CREA - Research Centre for Food and Nutrition, Rome, Italy
}

The fresh-cut industry supplies the food market with healthy fresh fruit and vegetables and, in that way, may contribute to improve the nutritional status of the general population. On the other hand, over the last few years increasing concerns have been raised regarding the environmental impact of the fresh-cut industry, human health risks from exposure to disinfection by-products found in fresh-cut products and chlorine-based disinfection treatments during produce processing. This review provides a comprehensive view of the main interlinked aspects related to food safety and environmental impact of processing of fresh-cut vegetables. Advantages and downsides of the mainstream disinfection strategy, based on the use of chlorine-related disinfecting agents, along with some alternative treatments close to a wide commercial application, are discussed. Limitation in the application of these strategies to processing of organic fresh-cut produce are also highlighted, examining the specific environmental and food safety problems in the organic sector. Areas where lack of available information hinders at present a clear understanding of priorities of research and action are pointed out. Innovative conceptual tools are proposed to address these multiple and interlinking issues and to overcome limitations of currently available technologies. A comprehensive and multidisciplinary approach is suggested to move toward a more safe and environmentally sustainable production of fresh-cut products.

Keywords: minimally processed, food safety risk assessment, environmental impact, regulatory framework, chlorine, ozone, peroxyacetic acid, organic produce

\section{INTRODUCTION}

The fresh-cut fruit and vegetables $(\mathrm{F} \& \mathrm{~V})$ market in the high-income economies has been characterized since the eighties by a rapid double-digit growth and it is now forecast to develop at an even faster pace in the middle-income economies (Rojas-Graü et al., 2011; Baselice et al., 2017). These consistent and continuing market trends have been attributed to the freshness, convenience, and healthy attributes of ready-to-eat F\&V. Convenience, along with sustainability and chemicalfree/organic nature, is currently viewed as one of the main drivers of the European F\&V market trends (CBI, 2021). In Europe the fresh-cut F\&V market is dominated by ready-to-eat salads, with market share ranging from 50 to $70 \%$ of total fresh-cut F\&V market, the remaining share being composed by fresh-cut fruits, and ready-to-cook vegetables and crudités (Fusi et al., 2016; Baselice et al., 2017). 
The increased availability of fresh-cut F\&V on the market has been favorably evaluated from a nutrition perspective, because it might facilitate an increased consumption of $F \& V$ in the general population. In this way it may contribute to efforts toward the yet-to-be achieved goal of a daily F\&V consumption of $400 \mathrm{~g}$ per capita, which is recommended by the WHO as the minimum intake needed for a healthy diet (World Health Organization, 2020). According to the European Fresh produce Association, the average intake of $\mathrm{F} \& \mathrm{~V}$ in Europe is estimated at $\sim 364 \mathrm{~g}$ per day per capita, formed by $212 \mathrm{~g}$ of fresh fruit and $152 \mathrm{~g}$ of fresh vegetables (Freshfel, 2021). Twenty-one out of 27 European Member States are not reaching on average the minimum consumption level recommended by WHO (Freshfel, 2021). An increased consumption of F\&V, along with wholegrain cereals, legumes and nuts, would be also important to achieve one key objective set up by the European Farm to Fork Strategy, that is reversing by 2030 the rise in obesity rates and overweight, which now affects more than half of the European adult population (European Commission, 2020a). Moreover, there is now a broad consensus that moving to a more plantbased diet, with less red and processed meat, would reduce not only risks of life threatening diseases, but also the environmental impact of the food system (Willett et al., 2019).

Besides the above mentioned potential benefits of the availability of fresh-cut F\&V on the market, in recent years concerns has been increasingly raised regarding the environmental sustainability of the fresh-cut industry (Manzocco et al., 2015; Ölmez, 2017), along with food safety issues related to fresh-cut produce (Gil et al., 2011; Gil and Allende, 2018). These downsides are mainly associated to the processing phase. The aim of this review is to discuss recent available information on the food safety and environmental implications of the processing process of fresh-cut vegetables, focusing on studies published in the last years (2015-2021). The specific aim of this review is to provide a comprehensive view of all the main critical food safety and environmental issues related to the processing of freshcut vegetables, whereas in the past most papers have examined them separately. By this comprehensive approach, critical current research gaps are tentatively identified, and new conceptual and methodological tools are proposed to address the complex interlinkages between the different aspects of this issue.

\section{PRELIMINARY REMARKS ABOUT THE NUTRITIONAL VALUE OF FRESH-CUT PRODUCE}

The contribution of fresh-cut products to the health benefits associated to the global consumption of $F \& V$ is retained if it is possible to assume that the operations involved in freshcut production process do not substantially alter the nutritional value of the freshly harvested product. A lot of studies have been carried out on the effects of processing and storage on the content of vitamins and bioactive phytochemicals in freshcut products, focusing on different species, cultivars, treatment and storage conditions (Gil and Kader, 2008; Barrett et al., 2010). Partly due to the great heterogeneity of the evaluated species and conditions, it is difficult to draw general conclusions about the effects of processing on the content of vitamins and phytochemicals in fresh-cut products. Contradictory results have been reported even in the case of different studies dealing with the same vegetable species subjected to similar treatments (De Ancos et al., 2011). Moreover, most of these experimental results were obtained in laboratory experimental settings that were often poorly representative of real industrial processing conditions. In any case, it deserves to be highlighted that the health benefits attributed to the consumption of fresh $\mathrm{F} \& \mathrm{~V}$ are not exclusively related to the content of vitamins and phytochemicals. A very important role is generally attributed also to other constituents, such as minerals and, most importantly, dietary fiber, which are expected to be negligibly affected by the processing and storage conditions of fresh-cut products. For instance, there is strong evidence that protection conferred by most plant-based foods against many chronic diseases is linked to the associated intake of dietary fiber (The Nordic Council, 2012). Moreover, the same health protection is significantly due to the low energy density and physico-chemical properties of plant-based foods, which can contribute to weight maintenance, while obesity and excessive body fat are established risk factors for most chronic diseases (Bes-Rastrollo et al., 2006; Boeing et al., 2012). Thus, the low energy intake and the intake of dietary fiber seem to play a major role in the health benefits associated to F\&V consumption. On the contrary, it is not certain that the occurrence of a minor, though statistically significant, difference in the content of some phytochemical compound might always make a big difference. Based on all these remarks, it seems reasonable to assume, as a first approximation, that nutritional value and health-related properties of fresh-cut products, considered as a whole, are not substantially different than those of the non-processed fresh counterparts. On the contrary, significant differences between fresh-cut $F \& V$ and the corresponding non-processed fresh products arise on the side of food safety (Gil et al., 2011; Gil and Allende, 2018) and environmental sustainability of the whole production process (Fusi et al., 2016) and are associated to the processing phase.

\section{PROCESSING OF FRESH-CUT VEGETABLES: THE CRUCIAL STEP OF WASHING/DISINFECTION}

Main steps of processing of fresh-cut vegetables are reported in Figure 1. Many studies in the last decades have led to the identification of washing/disinfection, among all the processing steps, as the most critical one, due to its crucial impact on the safety and quality of the final product (Gil et al., 2012; Gil and Allende, 2018) and on the environmental sustainability of the whole process (Fusi et al., 2016). Several machine types are used in the fresh-cut industry for the washing step but, apart of differences in design, they generally operate by conveying the product into a water tank, where it is subjected to an upward flow of air bubbles or pressurized water, and where water may contain or not a disinfecting agent (Gil et al., 2011). After a washing time of few minutes, the product is carried outside of the tank 
and eventually rinsed with clean water, if previously exposed to a disinfecting agent (Figure 2). The washing step is needed in the processing of fresh-cut vegetables because they are substantially different from the non-processed counterpart, mainly due to two kinds of reasons. First, cutting operations deprive the vegetable from the outer skins and peels that normally protect the internal tissue from microbiological invasion, while allowing juices to leak from the inner tissues onto the vegetable surface. These effects of cutting explain the reason why microbial growth is much greater on a minimally processed product as compared with the corresponding intact product (Hurst, 2002). Thus, large microbiological populations, including potentially high levels of human pathogen, may develop on the surface of cut produce. It is worth mentioning that these factors may have a different impact depending on the vegetable type. For example, in the case of baby leaves processing involves neither leaf cutting, nor elimination of external leaves/cores, thus reducing the impact of the processing operations on the related microbiological issues. Second, in many cases, as for salads, fresh-cut vegetables are ready-to-eat products, that are sold to be consumed raw, just upon opening of the bags, without additional home washing or preparation. For these reasons ready-to-eat fresh-cut products would entail an increased risk of foodborne disease outbreaks. These differences from intact vegetables justify the need for a specific regulation referred to ready-to-eat fresh-cut produce, which specify criteria related to the control of pathogens level in marketed products and during the manufacturing process (European Commission, 2005, 2007).

A basic approach for the washing step involves the use of potable water, without any disinfecting agent, and the first purposes that may be achieved by such treatment are product pre-cooling, removal of dirt and pesticide residue, removal of cell exudates that stick to the product cut surfaces and reduction of microbial load. Generally, the microbial load of vegetables entering the fresh-cut industry may range from 5 to 9 logarithmic units, whereas an average reduction of about $1 \log$ unit may be achieved upon washing, due to the sole mechanical removal effect by the water turbulent flow (Manzocco et al., 2015). However, the main drawback of washing with simple potable water is that organic matter tends to quickly accumulate within the washing tank if water is not continuously renewed. This may promote microbial proliferation in the processing washing water and, thus, in turn, cause cross contamination of the new product freshly conveyed into the washing tank. To minimize this risk an increased rate of water turnover could be applied (Holvoet et al., 2012), but the high operational costs of water use hinder this approach (Luo, 2007). Moreover, in general, it is not known how large the amount of water needed to minimize the risk of cross-contamination should be, whereas according to Gil et al. (2011) even the use of large amount of potable water would not eliminate this risk.

The above reasons are generally put forward in the scientific literature to justify the need of the application of a disinfection treatment. The purpose of the treatment would not be to completely decontaminate the product, but to control the level of microbial load within the washing tank and, thus, to minimize the risk of cross-contamination. This approach would guarantee a satisfactory level of microbiological quality of the final product,

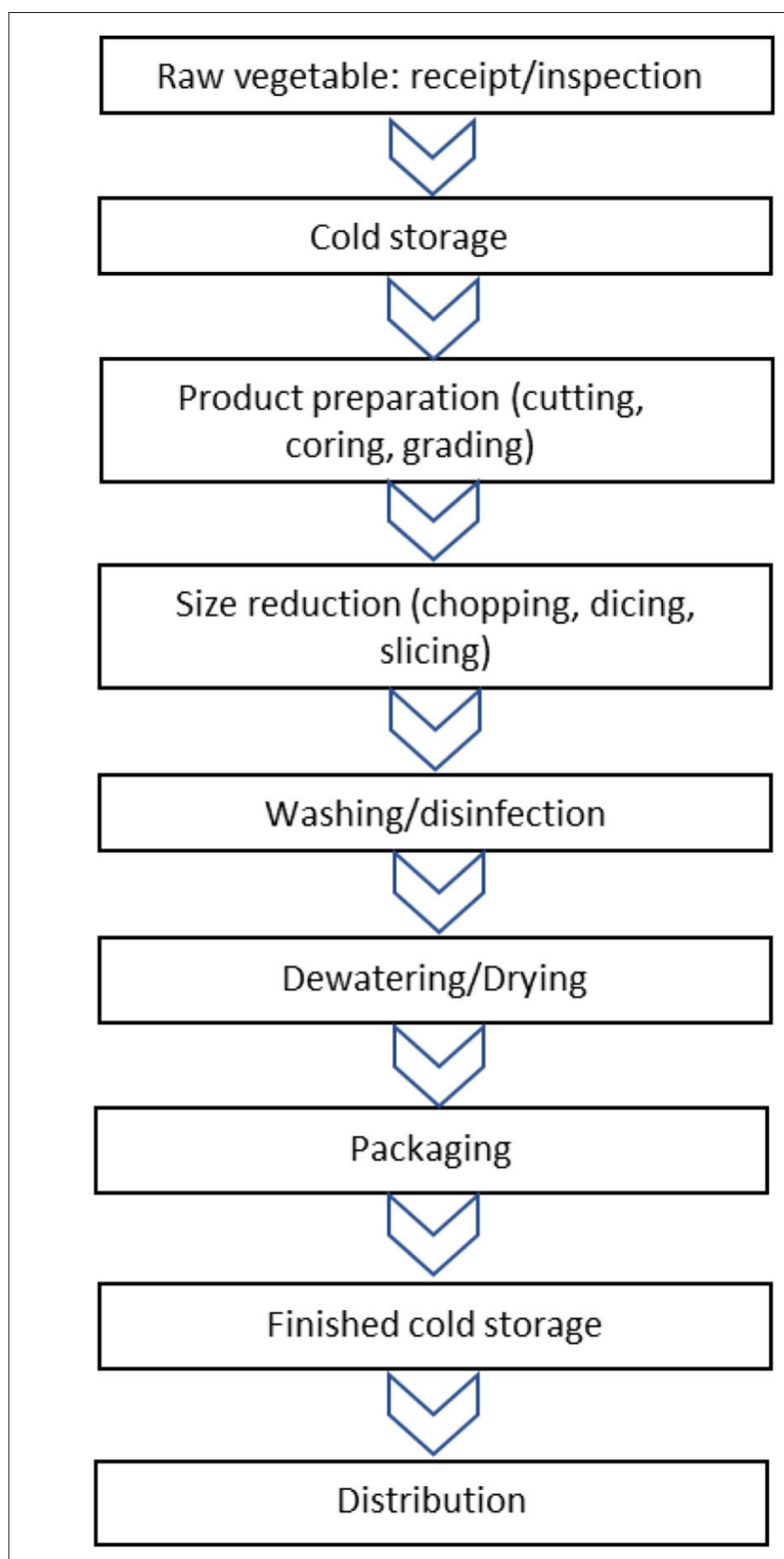

FIGURE 1 | Product flow diagram in a typical fresh-cut vegetables production process.

while allowing to reduce the rate of water turnover and the consumption of water needed for the whole process (Manzocco et al., 2015; Gil and Allende, 2018).

\section{DISINFECTING AGENTS: CHLORINE}

The most widespread approach for disinfection of process washing water is based on the use of chlorine, that is generally applied as liquid, in the form of sodium hypochlorite $(\mathrm{NaOCl})$ or calcium hypochlorite $\left[\mathrm{Ca}(\mathrm{OCl})_{2}\right]$ solution, or as a gas, in the form of chlorine $\left(\mathrm{Cl}_{2}\right)$ or chlorine dioxide $\left(\mathrm{ClO}_{2}\right)$. Reasons for the widespread adoption of these agents are the established 


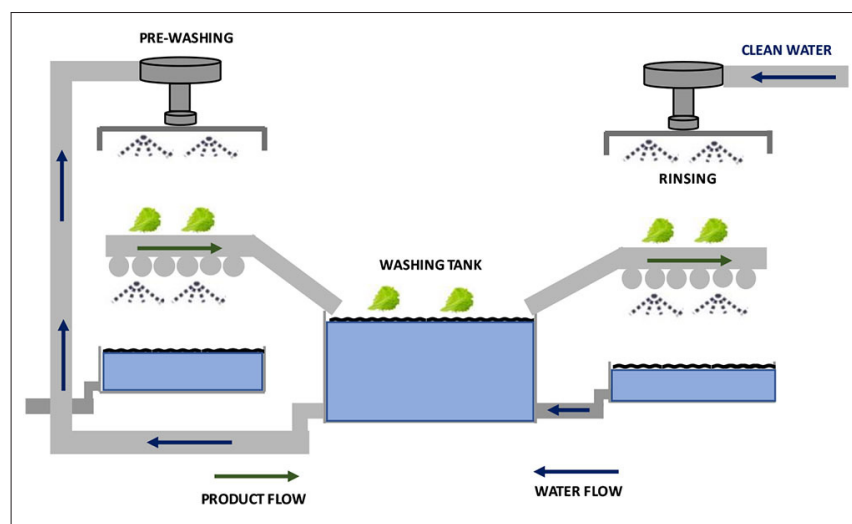

FIGURE 2 | Schematic diagram of the washing/disinfection processing unit for fresh-cut vegetables.

knowledge of conditions and effects of their use in water disinfection, ease of application, good cost effectiveness in an industrial setting, and their antimicrobial efficacy by a short contact time in chilled water (Goodburn and Wallace, 2013; Gil and Allende, 2018).

\section{Chlorine. Environmental Issues}

On the other hand, several disadvantages of chlorine have been highlighted. The first one is that, even though reduced by the use of chlorine, the amount of water needed for the washing operations is still huge. In the fresh-cut industry the global consumption of water ranges from 2 to 11 cubic meters per ton of product, and in the case of leafy vegetables about $90 \%$ of this water consumption is estimated to be due to the washing step (Ölmez, 2017). In general, water used in food processing plants has impacts at local, regional, and global levels, due to its uptake from local resources (Moravicki, 2012). In the case of the fresh-cut industry, which in many cases tends to develop in geographically concentrated and specialized industrial districts, this impact may be remarkable on aquifers at a local level. A second important disadvantage of the use of chlorine is the high amount of highly polluted wastewater generated by the process. It is estimated that in the fresh-cut industry a range from 11 to 23 cubic meters of wastewater are generated per ton of product (Ölmez, 2017). These levels fall within the range from about 5 to 70 cubic meters per ton of product, which has been reported for average levels of wastewater produced by the whole industrial sector of processing of fruits and vegetables in the USA (Moravicki, 2012). In the case of the fresh-cut industry, pollution of wastewater is mainly linked to the high organic load and to the presence of Disinfection By-Products (DBPs) associated to the use of chlorine (Ölmez, 2017). In general, effluents coming out of processing plants needs treatment before they are returned to water bodies, which require more energy and chemicals. Production of energy and chemicals both involve the release of carbon dioxide in the atmosphere (Moravicki, 2012), thus, wastewater treatment has an indirect impact on greenhouse gases emission. Moreover, according to the opinion of Ölmez (2017) the main impact of the fresh-cut industry on water resources is due to the highly polluted wastewater discharges rather than the amount of water used.

In line with the above observations, the environmental burdens of the whole manufacturing process of fresh-cut salad, as evaluated by application of the Life Cycle Assessment (LCA) methodology, have resulted to be heavily influenced by the processing phase (Fusi et al., 2016). According to this evaluation, both the washing and the packing steps had the highest impact, due to electricity and water consumption. Electricity used both for the washing and packaging phases as well as for the refrigerated storage at the plant facility was estimated at 0.109 $\mathrm{kWh}$ for the production of a package of salad (130 g). Additional electricity consumption was associated to the operation of the wastewater treatment plant (Fusi et al., 2016). On the contrary, the contribution related to the production and disposal of packaging material resulted to be of minor importance. Interestingly, the Authors noted that their evaluation did not assign any characterization factor to the use of chlorine and to the formation of its by products, while the effects associated to their eco and human toxicity could deserve a further consideration. Moreover, the Authors estimated that the application of a proper filtration treatment would accomplish for a recovery of $40 \%$ of the washing solution, while reducing the amount of the water used in the washing step. This could represent an effective solution to improve the environmental performance of the freshcut industry. In line with this approach, a more recent LCA study has estimated the reduction of the environmental load that could be achieved by the application of four novel filtration technologies (Vigil et al., 2020). All the novel technologies showed a decreased environmental burden that was mainly due to the decrease in water consumption, which, in turn, implied a decreased consumption of electricity for water cooling and pumping. The environmental gains were also maintained even if the increases in water recirculation rates were limited and/or the addition of reduced amounts of chlorine were still needed to ensure an acceptable level of produce quality. These results from lab scale investigations were promising from the perspective of the reduced environmental impact. However, they should be corroborated by experimental studies at the industrial scale to evaluate the suitability of these technology in ensuring also acceptable levels of food safety and quality.

From a regulatory perspective, it has been observed that, while at present in the European Union only potable water can be used in direct contact with food products during processing (European Commission, 2004), there are important differences in the water quality characteristics between potable, clean and nonpotable water. Taking this into account, it has been suggested that regulatory agencies should consider the possibility of including the use of water of appropriate quality for a particular application, which could be defined as "suitable for intended use," rather than restricting the possibility to the sole use of potable water (Gil and Allende, 2018). This could help producers adopt solutions for reuse of wash water, thus reducing the amount of potable water used in the process. 


\section{Chlorine. Food Safety Issues}

Other disadvantages of the use of chlorine are linked to the occurrence of residues of DBPs in the final product. There are two main groups of DBPs: the first is a group of chemicals that are formed in the water by reaction of chlorine with organic matter. This group includes trihalomethanes (THMs), haloacetic acids (HAAs), haloacetonitriles (HANs), halonitromethanes, haloacetamides, haloketones, chloral hydrate, and chloripicrin, that are formed when chlorine reacts with organic matter, whereas bromo THMs, HAAs, and HANs are formed when bromine is present in the water (Anand et al., 2014; Lee et al., 2019). Some of these compounds are harmful to human health and for this reason maximum contaminant levels are established for them in drinking water. In the USA the regulation levels are set at $80 \mu \mathrm{g} / \mathrm{L}$ for the total four trihalomethanes (including chloroform, bromodichloromethane, dibromochloromethane, and bromoform), $60 \mu \mathrm{g} / \mathrm{L}$ for the total five haloacetic acids (USEPA, 2006), whereas in the EU only total THM concentrations are regulated with a maximum contaminant level of $100 \mu \mathrm{g} / \mathrm{L}$ (European Commission, 1998). Other groups, such as haloacetonitriles, halonitromethanes, and haloacetamides, raise concerns due to their potential higher toxicity and are now viewed as emerging chlorination DBPs. Among them, the WHO has recently set guideline values for dibromoacetonitrile and dichloroacetonitrile at 70 and at $20 \mu \mathrm{g} / \mathrm{L}$, respectively, in drinking water (World Health Organization, 2017). At present regulations or guidelines on the levels of DBPs have been adopted only for drinking water but not for foods, even though safety risks associated to the presence of DBPs residues in foods from the use of chlorinebased sanitizers have been highlighted (FAO/WHO, 2008). In the literature few data have been reported on DBPs residues in freshcut products, and mainly limited to THMs and HAAs (Lee et al., 2019). As an additional problem, these limited data are often quite contrasting. Large differences have been found in the levels of DBPs not only on samples obtained by laboratory washing tests, but also on products purchased from the market, ranging from few ng $\mathrm{g}^{-1}$ (Gómez-López et al., 2013; Fan and Sokorai, 2015) to more than $1000 \mathrm{ng} \mathrm{g}^{-1}$ (Coroneo et al., 2017). Many factors may have contributed to this great variability, included the lack of a robust and validated analytical method for the quite challenging quantification of these compounds (Lee et al., 2019). Moreover, most data come from laboratory tests that in many cases were poorly representative of washing conditions at an industrial setting. The scarcity of data on this groups of DBPs residues in fresh-cut products has been recognized as a significant hindrance to achieve a satisfactory assessment of the related food safety risk (FAO/WHO, 2008; Lee et al., 2019).

A second group of DBPs that may residue on fresh-cut products is represented by chlorates. Chlorate $\left(\mathrm{ClO}_{3}{ }^{-}\right)$is an anion that can form salts, e.g., with sodium, which are strong oxidants. Based on this property, since the nineties, chlorates were used as herbicides and biocides in agriculture, but in 2008 chlorate was banned in the EU for its application as pesticide, due to its harmful effects on human health, taking into consideration the unacceptable exposure for operators (European Commission, 2008a). Thus, at present, chlorate may only residue as a DBP, when using chlorine, chlorine dioxide or hypochlorite, for the disinfection of drinking water, water for food production and surfaces coming into contact with food (European Food Safety Authority, 2015). In the case of disinfection of water for the food industry, chlorate occurrence as DBP is commonly due to its presence in the hypochlorite reagents, where it forms by disproportionation reaction of chlorine that is slowly converted to chloride and chlorate (Gil et al., 2016). As a consequence, in the fresh-cut processing, in general, the higher the amount of hypochlorite solution is added to the washing water the higher level of chlorate residue will result on the final product (Garrido et al., 2019). The risks to human health related to the presence of chlorate in food has been assessed in EU by the EFSA (European Food Safety Authority, 2015). According to this assessment inhibition of iodine uptake in humans was identified as the critical effect for chronic exposure to chlorate and a related tolerable daily intake (TDI) of $3 \mu \mathrm{g}$ chlorate $/ \mathrm{kg}$ body weight (b.w.) was established. The mean dietary exposures to chlorate in European countries exceeded the TDI in certain subgroups of the population. The assessment also recognized that the application of the WHO guidance level for chlorate in drinking water of $0.7 \mathrm{mg} / \mathrm{kg}$, as a hypothetical maximum residue limit (MRL) to all foodstuffs and drinking water, would only minimally reduce acute/chronic exposures and related risks. Also based on this assessment a recent EU Commission Regulation has set temporary maximum levels of chlorate in food, at levels which are "as low as reasonably achievable" (ALARA principle) by following good manufacturing practices, while ensuring at the same time that good hygiene practices remain possible (European Commission, 2020b). Limits have been set for specific food groups, such as leaf vegetables $(0.7 \mathrm{mg} / \mathrm{kg})$, root and tuber vegetables, including carrots $(0.15 \mathrm{mg} / \mathrm{kg})$, brassica vegetables, splitted in flowering brassica $(0.4 \mathrm{mg} / \mathrm{kg})$, head brassica $(0.07$ $\mathrm{mg} / \mathrm{kg}$ ) and leafy brassica (from 0.02 to $0.6 \mathrm{mg} / \mathrm{kg}$ ), and others. These limits have been established as temporary and are intended to be reviewed at the latest within 5 years of publication of the Regulation, in the light of possible developments in the area of hygiene, of drinking water, and further progress made by food business operators to bring chlorate levels down. Even for this reason, the adoption of the Regulation is expected to promote the development of innovations in the fresh-cut sector aimed at a further reduction of chlorate residue levels. The occurrence of these potentially harmful DBPs residues in fresh-cut vegetables sheds light on the challenging nature of the management of food safety of fresh-cut products by using chlorine-based disinfecting agents. In fact, the need of reducing the microbiological risk associated to bacterial pathogens may potentially come in conflict with the concurring need of minimizing the chemical risk associated to the formation of chlorine related DBPs.

\section{Chlorine. Food Quality Issues}

As regards quality attributes, a specific disadvantage of the use of chlorine as disinfecting agent is related to the occurrence of the characteristic familiar chlorine odor upon opening of the salad bags (Bett, 2002; IZSVe, 2015). The occurrence of this olfactory defect may critically undermine the image of product wholesomeness and naturalness, as perceived by the consumers. 
Chlorine solutions, as other sanitizers, can impart a flavor on produce if allowed to remain on the surfaces, giving rise to the perception of unpleasant off-odors (Bett, 2002). Despite the repeatedly reported occurrence of this defect, no information is available in the literature on the characterization of this off-odor in fresh-cut produce. According to studies on drinking water, it is plausible that volatile compounds that may contribute to the chlorine-like off-note are mainly chloramines and, at a lower level, chlorine itself. All these compounds are characterized by "chlorinous" and "swimming pool" odor notes (Dietrich and Burlingame, 2020) and are likely responsible for the chlorine off-notes rather than chloroform and other volatile chlorinerelated DBPs that have been found within fresh-cut salad bags (Díaz-Mula et al., 2017; Raffo et al., 2020, 2021). As mentioned above, chloroform and DBPs are formed by reaction of chlorine with organic matter, whereas chloramines are formed by reaction of chlorine with ammonia: the occurrence of ammonia, but not of the derived chloramines, has been recently observed in the headspace of packaged fresh-cut salads (Dryahina et al., 2020). It is plausible that technical challenges in the analytical determination of these volatile compounds have limited the chances of their detection and hindered a clear understanding of the molecular basis of the related off-odor along with the conditions that promote its development.

\section{Chlorine. Legal Issues}

An important limitation of the use of chlorine is related to the legal framework. At present the use of chlorine for disinfection of fresh-cut products is prohibited in some European countries, such as Belgium, Denmark, Germany, The Netherlands, Switzerland, based on national level restrictions. In addition, in Europe chlorine and related substances are not allowed to be used in the processing of organic fresh-cut products, based on the positive list of substances that can be used in the processing of organic food, as reported in Commission Regulation n. 889/2008 (European Commission, 2008b). The consequent need to develop alternative washing strategies for organic fresh-cut products, could have an increasing importance in the next future. In the EU the market of organic processed foods has been observed to grew at an average level of 6\% (Van den Berg, 2019), and a steady growth is expected for the next years. Moreover, within European Countries, an additional push to the growth of the market of organic processed foods could also come from the objective established in the Farm to Fork Strategy, as part of the European Green Deal, to reach at least 25\% of the EU's agricultural land under organic farming by 2030 (European Commission, 2020a).

\section{DISINFECTION STRATEGIES PROPOSED TO REDUCE OR REPLACE THE USE OF CHLORINE}

\section{Strategies for a Reduced Use of Chlorine}

Due to all these drawbacks efforts have been put in place to develop alternative disinfection strategies with the aim to reduce or replace the use of chlorine. Chlorine still being the mainstream option in many instances, a first line of intervention has been addressed to optimize conditions of washing water disinfection, with the objective to add the minimum chlorine amount needed to avoid cross-contamination while minimizing the formation of DBPs (Table 1). Different ranges have been reported for the level of chlorine commonly applied by the industry, from a minimum of $5 \mathrm{mg} \mathrm{L}^{-1}$ to a maximum of $200 \mathrm{mg} \mathrm{L}^{-1}$. Moreover, it has been shown that relatively low concentrations $\left(7-20 \mathrm{mg} \mathrm{L}^{-1}\right)$ could be sufficient to prevent potential cross-contamination associated with the reuse of wash water (Ölmez, 2017). However, managing washing systems at an industrial level to avoid hyperchlorination and keep in the washing water the needed level of free chlorine is far from being an easy task. This is due to the great variability of the physicochemical and microbiological properties of the wash water, which is caused by the constantly changing conditions of the production lines. Recent investigations have shown that obtaining empirical evidence of basic concepts of chlorination management at industrial scale is a quite complex task, as well as monitoring and controlling the free chlorine level in the processing wash water (López-Gálvez et al., 2019; Tudela et al., 2019a). These studies highlighted the need to optimize the operation of processing lines at commercial scale to reduce both microbial and chemical risks. A recent study has attempted to develop and validate a produce-specific (for cut carrots, cut green cabbage, and cut iceberg lettuce) mathematical model of free chlorine dynamics within washing tank that is consistent regarding free chlorine replenishment as well as across multiple experimental scales, such as laboratory or pilot plant scale (Srinivasan et al., 2020). According to the Authors, such models could serve as important tools aimed at validating free chlorine compliance within operational limits as well as guiding largescale commercial experiments focused on improving chlorine management strategies relevant for industry. Another study, performed at a laboratory scale and designed to establish lower and higher operational limits for the use of sodium hypochlorite in washing of fresh-cut produce, showed that for some types of vegetables it was not possible to establish higher operational limits based on the occurrence of DBPs (Tudela et al., 2019b). In these cases, even free chlorine levels as low as $10 \mathrm{mg} \mathrm{L}^{-1}$ caused an excessive concentration of chlorate in the wash water. The Authors also suggested that reduction of the accumulation of DBPs may be achieved by produce prewashing, thus lowering the level of chlorine to be added, or by increasing water replenishment rates, which would also increase water consumption.

\section{Strategies to Replace the Use of Chlorine}

Several methods are under investigation to replace to use of chlorine by applying biological-based methods, alternative chemical compounds and physical methods, or a combination of these approaches. Advantages and limitations of some of them are reported in Table 2. Recent reviews have given an updated information on these developments (Ölmez and Kretzschmar, 2009; Ramos et al., 2013; Manzocco et al., 2015; Meireles et al., 2016; Ali et al., 2018). Some methods have been shown to be promising alternative disinfection strategies by laboratory scale experiments but more research is needed to demonstrate their 
TABLE 1 | Summary of recent studies aimed at optimizing conditions of chlorine application during washing water disinfection.

\begin{tabular}{|c|c|c|c|c|c|}
\hline Study aim & Experimental setting & Measured parameters & Types of fresh-cut produce & $\begin{array}{l}\text { Free chlorine concentration } \\
\left(\mathrm{mg} \mathrm{L}^{-1}\right) \text { in washing water }\end{array}$ & References \\
\hline $\begin{array}{l}\text { Characterization of process wash water and } \\
\text { washed products }\end{array}$ & Commercial scale & $\begin{array}{l}\text { Physicochemical, microbial } \\
\text { spoilage, chemical } \\
\text { contaminants }\end{array}$ & $\begin{array}{l}\text { Baby leaves, fresh-cut lettuce, } \\
\text { shredded vegetables }\end{array}$ & Range: $40-60$ & $\begin{array}{l}\text { López-Gálvez } \\
\text { et al., } 2019\end{array}$ \\
\hline $\begin{array}{l}\text { Effect of conditions of chlorine application on } \\
\text { process wash water and washed products }\end{array}$ & $\begin{array}{l}\text { Processing lines at } \\
\text { commercial conditions }\end{array}$ & $\begin{array}{l}\text { Physicochemical, microbial } \\
\text { spoilage, chemical } \\
\text { contaminants }\end{array}$ & $\begin{array}{l}\text { Baby leaves, romaine, and } \\
\text { iceberg lettuce }\end{array}$ & $\begin{array}{l}\text { Liquid chlorine: manual } \\
\text { procedure: } 40-80 \\
\text { automatic procedure: } 10-20 \\
\text { Chlorine gas: } \\
\text { manual procedure: } 80 \\
\text { automatic procedure: } 10-20\end{array}$ & $\begin{array}{l}\text { Tudela et al., } \\
\text { 2019a }\end{array}$ \\
\hline Assessment of free chlorine operational limits & Laboratory scale & $\begin{array}{l}\text { Physicochemical, microbial } \\
\text { spoilage, chemical } \\
\text { contaminants }\end{array}$ & $\begin{array}{l}\text { Lettuce, baby leaves, cabbage, } \\
\text { diced onions }\end{array}$ & Levels: 0, 10, 20, 30 & $\begin{array}{l}\text { Tudela et al., } \\
2019 \mathrm{~b}\end{array}$ \\
\hline $\begin{array}{l}\text { Development of a produce-specific mathematical } \\
\text { model to predict free chlorine dynamics }\end{array}$ & Laboratory scale & Physicochemical & $\begin{array}{l}\text { Carrot, cabbage, iceberg lettuce, } \\
\text { lettuce }\end{array}$ & 25 & $\begin{array}{l}\text { Srinivasan et al., } \\
2020\end{array}$ \\
\hline $\begin{array}{l}\text { Quantitative microbial risk assessment model to } \\
\text { estimate cross-contamination during washing }\end{array}$ & $\begin{array}{l}\text { Computer simulation, } \\
\text { mathematical modeling }\end{array}$ & None & Leafy greens & Levels: 0, 5, 10, 25, 50, 150, 250 & Maffei et al., 2017 \\
\hline $\begin{array}{l}\text { Effects of physicochemical parameters on chlorine } \\
\text { demand of process wash water }\end{array}$ & Laboratory scale & Physicochemical & $\begin{array}{l}\text { Romaine lettuce, iceberg lettuce } \\
\text { fruits }\end{array}$ & $\begin{array}{l}\text { Levels: 50, 75, } 100 \text { (initial } \\
\text { chlorine level) }\end{array}$ & $\begin{array}{l}\text { Chen and Hung, } \\
2017\end{array}$ \\
\hline $\begin{array}{l}\text { Development of a chlorine dosing strategy to } \\
\text { maintain microbial safety and minimize residual } \\
\text { chlorine }\end{array}$ & Laboratory scale & $\begin{array}{l}\text { Physicochemical, microbial } \\
\text { spoilage }\end{array}$ & Lettuce, strawberry & Levels: 10, 30, 60, 90 & $\begin{array}{l}\text { Chen and Hung, } \\
2018\end{array}$ \\
\hline $\begin{array}{l}\text { Evaluation of the chlorate accumulation in process } \\
\text { wash water and in fresh-cut produce }\end{array}$ & $\begin{array}{l}\text { Commercial and } \\
\text { laboratory scale }\end{array}$ & $\begin{array}{l}\text { Physicochemical, chemical } \\
\text { contaminants }\end{array}$ & Lettuce & Levels: 3, 20-25 & Gil et al., 2016 \\
\hline $\begin{array}{l}\text { Influence of conditions of water chlorination on } \\
\text { efficacy in preventing cross-contamination }\end{array}$ & Laboratory scale & $\begin{array}{l}\text { Physicochemical, microbial } \\
\text { spoilage }\end{array}$ & Lettuce & Prewash levels: 0, 5, 20, 30 & Fu et al., 2018 \\
\hline $\begin{array}{l}\text { Determination of the minimal free chlorine } \\
\text { concentration for preventing cross-contamination } \\
\text { during produce washing }\end{array}$ & Commercial scale & $\begin{array}{l}\text { Physicochemical, microbial } \\
\text { spoilage }\end{array}$ & $\begin{array}{l}\text { Chopped lettuce, shredded } \\
\text { lettuce, diced cabbage }\end{array}$ & $\begin{array}{l}\text { Range: } 0-22.5 \\
\text { Average levels: } 6.5 \text { (romaine), } \\
11,5 \text { (iceberg), } 16.8 \text { (cabbage) }\end{array}$ & Luo et al., 2018 \\
\hline $\begin{array}{l}\text { Effect of } \mathrm{pH} \text { regulators on chlorine concentration in } \\
\text { process wash water }\end{array}$ & Laboratory scale & $\begin{array}{l}\text { Physicochemical, microbial } \\
\text { spoilage, chemical } \\
\text { contaminants }\end{array}$ & Lettuce & 25 & Marín et al., 2020 \\
\hline $\begin{array}{l}\text { Relationship between oxidation reduction potential } \\
\text { and free chlorine during fresh produce washing }\end{array}$ & Laboratory scale & Physicochemical & $\begin{array}{l}\text { Carrots, onions, romaine, and } \\
\text { iceberg lettuce }\end{array}$ & Levels: 0, 100 & $\begin{array}{l}\text { Van Haute et al., } \\
2019\end{array}$ \\
\hline $\begin{array}{l}\text { Method by UV absorbance determination for } \\
\text { predicting chlorine demand in process wash water }\end{array}$ & Laboratory scale & Physicochemical & Cabbage, carrot, lettuce, onion & Whole range tested: 0-400 & $\begin{array}{l}\text { Van Haute et al., } \\
2018\end{array}$ \\
\hline $\begin{array}{l}\text { Estimation of chlorine demand input and chlorine } \\
\text { decay kinetics of fresh-cut produce wash water }\end{array}$ & Laboratory scale & Physicochemical & $\begin{array}{l}\text { Romaine lettuce, iceberg lettuce, } \\
\text { carrot, baby spinach }\end{array}$ & $\begin{array}{l}\text { Free chlorine levels not reported. } \\
\text { Only chlorine demand levels } \\
\text { reported: } \\
\text { 0-700, whole range tested }\end{array}$ & Weng et al., 2016 \\
\hline $\begin{array}{l}\text { Mathematical model to predict physicochemical and } \\
\text { microbiological parameters in process wash water }\end{array}$ & $\begin{array}{l}\text { Laboratory scale, } \\
\text { mathematical modeling }\end{array}$ & $\begin{array}{l}\text { Physicochemical, microbial } \\
\text { spoilage, }\end{array}$ & Baby spinach leaves, lettuce & Range: 0-13 & Azimi et al., 2017 \\
\hline
\end{tabular}


effective use at industrial scale. In the present review an update is given for some methods that are close to a validation or to a wide application at an industrial level.

\section{Peroxyacetic Acid}

Peroxyacetic acid $\left(\mathrm{CH}_{3} \mathrm{CO}_{3} \mathrm{H}\right)$, also named as peracetic acid (PAA), is the peroxide of acetic acid and is commercially available as a quaternary equilibrium mixture of acetic acid $\left(\mathrm{CH}_{3} \mathrm{CO}_{2} \mathrm{H}\right)$, hydrogen peroxide $\left(\mathrm{H}_{2} \mathrm{O}_{2}\right)$, peroxyacetic acid, and water. Properties of PAA such as ease of implementation, relatively low cost, broad spectrum of antimicrobial activity given organic matter presence, short contact time, limited dependence on $\mathrm{pH}$, lower tendency to form chlorinated DBPs than chlorine, calls for its advantageous use in disinfection of fresh-cut produce (Banach et al., 2015, 2020). Evaluation of managerial criteria, such as costs and complexity of operation, has led to the conclusion that PAA is a cost-effective technology on a lower scale application, whereas maintenance and operation are relatively simple, similarly to sodium hypochlorite treatment (Banach et al., 2015). However, its lower antimicrobial efficacy, when compared to chlorine, has been judged not sufficient to obtain a substantial reduction in the microbial load of fresh-cut produce in some experimental studies (Ölmez and Kretzschmar, 2009). On the contrary, a recent investigation conducted under an industrially environment suggested that a solution of PAA (at $75 \mathrm{mg} \mathrm{L}^{-1}$ ) could be an effective disinfectant for processing of fresh-cut lettuce (Banach et al., 2020). Moreover, a definite advantage of PAA application over sodium hypochlorite could be the lower level of toxic by-products formed by its use. Results from a recent study at a laboratory scale clearly demonstrated that washing by PAA generated much less DBPs than washing by sodium hypochlorite (Lee and Huang, 2019). From the regulatory point of view, in the USA PAA is considered a Generally Recognized As Safe (GRAS) compound and it is included in the list of chemicals allowed to be used in washing of fruits and vegetables, with the limitation of maximum concentration of $80 \mathrm{mg} \mathrm{L}^{-1}$ in wash water (FDA-USDA, 2021a). As regards the organic sector, as stated by current European regulation on organic food processing (European Commission, 2008b), the use of PAA it is not allowed for washing of organic freshcut vegetables. Regarding the environmental dimension, no information is available on the effect of this disinfection strategy on the amount of water consumed. As regards the quality of wastewater, as mentioned above, treatment with PAA is capable to reduce both the number and amount of potential ecotoxic DBPs that may residue in the wastewater after produce washing (Lee and Huang, 2019).

\section{Ozone}

Ozone $\left(\mathrm{O}_{3}\right)$ is a partially water soluble gas, which is a strong oxidant that can elicit high antimicrobial activity (Ölmez, 2012). It can be applied for disinfection of fresh-cut produce both dissolved in water and as gas (Meireles et al., 2016; Aslam et al., 2020). Several lab scale investigations have demonstrated that ozone produces a microbial log reduction similar to chlorine (Goodburn and Wallace, 2013). Interestingly, a recently proposed approach, based on the combined action of ozone and lactic acid, suggested that hurdle technology may allow for an increased antimicrobial efficacy compared to independent disinfection strategies (Wang et al., 2019). One of the key advantages of ozone is the lack of production of chlorinated DBPs (Ölmez, 2012). This advantage is partially offset by the production of highly toxic brominated DBPs, when bromide is present in the washing water. Moreover, most of assimilable organic carbon formed from ozonation is not characterized yet, and little is known about its potential health effects (Richardson and Postigo, 2012). A recent study, while demonstrating the efficacy of ozonation in disinfection of washing water from the fresh-cut industry, also showed an increased acute ecotoxicity of the treated wash water, which highlighted the need of further studies aimed at characterizing and reducing the generated toxicity (Nahim-Granados et al., 2020). Other disadvantages are represented by the need to be generated in situ and by its strong oxidant power that may cause corrosion of equipment metal surfaces. Moreover, it is highly toxic when inhaled and, for this reason, its level must be strictly monitored and controlled in the working environment (Ölmez and Kretzschmar, 2009; Meireles et al., 2016). Despite these disadvantages, ozone has been judged as the most promising chlorine-free disinfection strategy for fresh-cut produce, showing the best ratio along with chlorine in relation to the efficacy in reducing pathogenic microorganisms and the cost effect (Ölmez and Kretzschmar, 2009; Manzocco et al., 2015). As regards environmental issues, ozone has also been suggested as the best available technique, also in relation to the production and the reuse of wastewater (Ölmez and Kretzschmar, 2009). Also related to environmental issues, another hurdle technology approach, combining ozonation and UV irradiation, has been proved promising for potential reduction of water consumption (SUSCLEAN, 2015). A recent investigation on the use of sprayed ozonated water in the processing of intact fresh carrots, also suggested that this technology could markedly reduce several environmental impacts with respect to a standard processing line (Paulikiene et al., 2020). From the regulatory point of view, in the USA ozone has gained the GRAS status and can be used in food processing, included raw agricultural commodities (FDAUSDA, 2021b). Similarly to PAA, its use is not allowed by current European regulation on processing of organic foods (European Commission, 2008b).

\section{Electrolyzed Water}

Electrolyzed water (EW), or Electrolyzed Oxidizing Water (EOW), is a new chlorine-based disinfection technology, which takes advantage of the electrochemical treatment of a diluted sodium chloride $(\mathrm{NaCl})$ solution to produce electrolyzed acidic water at the anode and electrolyzed basic solution at the cathode, or neutral electrolyzed solution obtained by mixing these solutions (Gil et al., 2015; Manzocco et al., 2015; Meireles et al., 2016). Different types of EW generators have been proposed, with different electrolyzed water solution properties. Generally, the antimicrobial activity has been attributed to the activity of oxidant substances, e.g., chlorine substances, such as hypochlorous acid, but also non-chlorine substances, such as $\mathrm{O}_{3}$ and $\mathrm{H}_{2} \mathrm{O}_{2}$ (Gil et al., 2015). All these oxidants are produced 
TABLE 2 | Advantages and limitations of alternative disinfection methods proposed to replace the use of chlorine.

\section{Disinfection method \\ Chemical-based methods \\ Peroxyacetic acid}

Ozone

\section{Electrolyzed water}

Hydrogen peroxide

Organic acids (citric, malic, lactic acid)

\section{Easy to apply}

No formation of DBPs

\section{Biological-based methods}

Bacteriocins, bacteriophages, enzymes

\section{Physical-based methods}

Ultraviolet (UV) radiation

Ultrasounds water

Lower corrosiveness

Not corrosive

Easy to apply

Low cost

Environmental friendly

Harmless to human health

Strong antimicrobial activity

Easy to use

maintenance
Allowed for organic products

Based on the use of salt and water No need to handle chlorine solution Reduced concentration of chlorine in the wash

No formation of chlorinated DBPs

Specificity of antimicrobial activity

Reduced effects on product sensory quality

GRAS status (e.g.,nisin)

No formation of toxic by-products

Low cost of equipment, energy, and

Useful application for wastewater treatment

No formation of toxic by-products

Environmental friendly

Useful in combination with other

disinfection technologies

Combination of disinfection methods

Ozone + UV radiation

Ozone + calcium lactate

Ozone + citric acid

Ozone + lactic acid

UV radiation + ultrasounds

Sodium bicarbonate + hydrogen peroxide

UV radiation + PAA

Wider antimicrobial action

Increased antimicrobial efficacy

Reduced chlorine dosage (when applied in

combination with chlorine)
Limitation/disadvantages

References

Lower antimicrobial efficacy at permitted level Banach et al., 2015

Not allowed for organic products Banach et al., 2020

Gil and Allende, 2018

Meireles et al., 2016

Ölmez, 2017

Toxic when inhaled

In situ generation needed

Corrosive on equipment surfaces

Formation of brominated DBPs

High investment cost

Not allowed for organic products

Aslam et al., 2020

Manzocco et al., 2015

Meireles et al., 2016

Nahim-Granados et al., 2020

Paulikiene et al., 2020

Ölmez, 2017

SUSCLEAN, 2015

Wang et al., 2019

High cost and limited availability of equipment Ali et al., 2018

Efficacy dependent on organic matter level in Gil et al., 2015

Gil et al., 2019

Little evidence of efficacy at a commercial level Gil and Allende, 2018

Not allowed for organic products Manzocco et al., 2015

Meireles et al., 2016

Ölmez, 2017

Fast disinfectant decomposition and slow

disinfection kinetics

Phytotoxic

Negative impact on product quality

Not allowed for organic products

Lower antimicrobial efficacy

Long contact time, not suitable to industrial

processing lines

Impact on product sensory quality

High COD and BOD of wastewater

Ali et al., 2018

Manzocco et al., 2015

Meireles et al., 2016

Ölmez, 2017

Manzocco et al., 2015

Meireles et al., 2016

Ölmez and Kretzschmar,

2009

Ölmez, 2017

Low antimicrobial efficacy

Meireles et al., 2016

Long contact time

Poorly suitable to conditions of industrial

processing lines

Need of mixture of disinfecting agents (of

enzymes)

High cost

Consumer acceptance to be verified

Negative impact on product sensory quality

Ali et al., 2018

Low efficacy at high organic matter level

Meireles et al., 2016

Complex standardization of application at

commercial scale

Consumer acceptance to be verified

Limited antimicrobial efficacy Ali et al., 2018

Dependent on organic matter, water hardness, Gil and Allende, 2018

dissolved gases

Meireles et al., 2016

Increased water temperature during application

Consumer acceptance to be verified
Complex standardization at commercial scale Ali et al., 2018

Consumer acceptance to be verified Aslam et al., 2020

Meireles et al., 2016

SUSCLEAN, 2015

Wang et al., 2019 
by the electrochemical treatment from the substances present in the aqueous $\mathrm{NaCl}$ solution. Thus, this technology does not use a direct source of chlorine, even though chlorine-related substances are the main active compounds involved in the disinfection action. From this point of view, it only partially replaces the use of chlorine. One aspect of the environmental friendly character of this approach is that it needs only a diluted $\mathrm{NaCl}$ water solution to prepare the disinfecting solution. This solution can be produced on-site at the concentration ready to use, while avoiding the risks associated to the handling of chlorine solution. In addition, some investigations have highlighted that EW solutions may have an antimicrobial activity similar to that of hypochlorite solutions containing free chlorine at a higher concentration. This, in theory, should allow for a decreased level of chlorine compounds in wash water without reducing the disinfection efficacy (Manzocco et al., 2015). However, a recent study performed by a pilot plant showed that washing by EW resulted in a higher accumulation of chlorine DBSs in processing water than washing by conventional hypochlorite solution (Gil et al., 2019). Moreover, a filtration treatment by activated carbon significantly reduced the concentration of DBPs in water, leading to a lower concentration of DBPs in the washed produce. Another disadvantage of this technology is the relatively high initial investment cost. At present most of performance information available on EW has been obtained from experimental studies at lab scale, while operational ranges, performance and costs evaluated at this level are poorly representative of the corresponding one at industrial level (Gil and Allende, 2018). From the regulatory point of view, being a chlorine-based disinfection treatment, the use of EW in the freshcut industry is allowed only in those countries where chlorine can be used, such as USA, according to the Code of Federal Regulations (FDA-USDA, 2021a), and other countries, such as Spain, United Kingdom and Japan (Gil et al., 2015). It is not allowed in all European countries for organic food processing.

\section{Alternative Strategies for the Organic Sector}

According to the IFOAM (International Federation of Organic Agriculture Movements) norms for organic production and processing, techniques used to process organic products shall be biological, physical, and mechanical in nature (IFOAMOrganics International, 2018). The only chemical substances with disinfecting activity that are allowed to be used in the washing of fresh-cut produce as processing/post-harvest handling aids, are some organic acids, such as citric, malic, and lactic acid. On the contrary, more effective disinfecting agents, such as chlorine (in the form of hypochlorite or chlorine dioxide), ozone and peracetic acid, may only be used to cleanse and disinfect equipment that may come into direct contact with the product. The European regulation on organic food processing also allows for use of citric acid as processing aid for all foodstuffs of plant origin (European Commission, 2019). Organic acids are widely used as preservatives in the food industry and when used as disinfecting agents for the fresh-cut industry has the advantage toward chlorine-based disinfectants to avoid the formation of toxic by-products (Meireles et al., 2016). However, it has been observed that the exposure times needed for a significant reduction in the microbial load is very long and not suitable to the conditions of processing lines in the fresh-cut industry (Ölmez and Kretzschmar, 2009). In addition, to have a significant antimicrobial effect these acids should be used at a much higher concentration than sodium hypochlorite. This, in turn, may have a significant impact on the quality of the wastewater, due to a marked increase of the levels of both Chemical Oxygen Demand (COD) and Biochemical Oxygen Demand (BOD; Ölmez and Kretzschmar, 2009; Meireles et al., 2016).

\section{KEY DATA GAPS FOR THE EVALUATION OF FOOD SAFETY RISKS, ENVIRONMENTAL IMPACTS, AND CONSUMERS' ACCEPTABILITY}

While in many instances it is not straightforward to select the optimum disinfection strategy, an upstream controversy is emerging about the real need of using a disinfection treatment at all. Most scientists conclude in the literature that washing with simple water, without any disinfection agent, is not safe enough, even when large amounts of water are used (Holvoet et al., 2012; Gil and Allende, 2018). However, some producers apparently do not agree to this statement and are moving toward washing approaches with simple potable water. They count on strict control of primary production conditions to lower the microbial load of produce entering the processing process, and on reduced temperature during processing operations. It has been noted that clarifying the issue about the need of using a disinfection treatment is far from being simple. This is because it is quite challenging and expensive to perform carefully controlled experimental studies on this question at industrial level. So far available data from industrial scale experiments for testing the disinfection capacity of produce washing remains limited (Gil and Allende, 2018). On the one hand, fresh vegetables, such as leafy vegetables, have been repeatedly reported as source of contamination by pathogenic Escherichia coli O157:H7, Salmonella spp., and Norovirus in outbreaks occurred in the USA and Europe in recent years (Callejón et al., 2015; Banach et al., 2020; Nahim-Granados et al., 2020; CDC, 2021). As explained above, the specific conditions of processing and consumption of fresh-cut vegetables are expected to increase the risks of foodborne disease outbreaks associated with fresh vegetables. On the other hand, it has been observed that the importance of cross-contamination during washing of fresh produce, in terms of public health relevance, has rarely been assessed (Chardon et al., 2016). By applying a mathematical model that simulated the dispersion of contamination from a load of leafy greens during industrial washing, a study highlighted that the relevance of cross-contamination during washing decreased when the initial contamination event was diffuse and uniform (Chardon et al., 2016). This is the case when it resulted from irrigation with contaminated water in the field. From these results it was concluded that prevention of contamination in the field is the most important risk management strategy and that disinfection 
of washing water can be an additional intervention to tackle potentially high $\left(>10^{6} \mathrm{CFU}\right)$ point contamination levels. Also based on this methodological approach, it has been observed that the key point for risk assessment is that pathogens are most likely introduced into the primary production environment by extremely heterogeneous distributions. This can occur when contamination originates from manure that is not homogeneously contaminated, and from rare events, due, for example, to introduction by wildlife excretions or flooding as a result of extreme weather. Based on these remarks, it has been concluded that risk assessment of fresh produce should shift from establishing baseline risks to quantifying likelihoods of rare events (Franz, 2018). To do so, more data would be needed, which could be achieved by in-depth analysis of occurring outbreaks, that, in turn, would require strong interactions between epidemiologists, microbiologists and the fresh produce processing industry (Franz, 2018). According to the opinion of Franz, the baseline incidence of illness associated with fresh produce is low, and fresh produce should be considered as a relatively safe component of a healthy diet. However, marked differences have been reported on this point between geographical areas: prevalence of vegetable contamination by pathogens is very low in European and North American countries, even though the occurrence of apparently associated outbreaks seem to be more frequent in the USA than in Europe in recent years (Franz, 2018). On the contrary, a much higher prevalence of contamination of minimally processed vegetables has been repeatedly reported in developing countries (Froder et al., 2007; Sant'Anna et al., 2020), where the highest increases in consumption of fresh-cut vegetables are forecast in the near future.

Another food safety issue where more research is needed regards the risk assessment of dietary exposure to DBPs, such as THM and other substances that are formed in the process water by the reaction of chlorine with organic matter. As mentioned above, the scarcity of reliable data on DBPs residues in fresh-cut produce makes at present hard to estimate the exposure to these substances linked to the consumption of fresh-cut vegetables (Lee and Huang, 2019). Moreover, toxicological evaluation of new emerging chlorine-related DBPs still remains to be addressed (Lee and Huang, 2019).

To evaluate the environmental impact of different disinfection technologies, it is of key importance the availability of data on this, and, in particular, of data obtained by experimental studies performed under an industrial environment. On the contrary, at present, few data from LCA studies have been published, and only limited to the mainstream chlorine disinfection treatment and to some novel filtration technologies. Very few data are available on water and energy consumption associated to other disinfection technologies. Similarly, limited information is available on the disinfection efficacy of the alternative strategies at industrial level, as well as on formation of the different classes of DBPs. A change of approach, from laboratory batch-wise experiments toward application at an industrial processing line, has been observed in recent years in this field of research. However, at present, this has been limited to a handful of studies (Ölmez, 2017; Luo et al., 2018; López-Gálvez et al., 2019; Tudela et al., 2019a). Lack of information on these crucial points precludes the possibility of a meaningful comparison of the different technologies as regards their environmental burden and food safety issues.

This lack of information is also a significant burden when evaluating the best option for the organic sector. In addition to perplexity about the disinfection efficacy of a washing treatment using only potable water with a higher rate of water turnover, it is not clear how much water should be used to guarantee an acceptable level of food safety. Besides, it is not clear until which point this increased consumption of water would be still in accordance with organic production principles, which require that water should be used efficiently and responsibly (IFOAMOrganics International, 2018).

Another important point to consider when evaluating alternative strategies to chlorine-based treatments is consumers' attitudes toward and acceptance of candidate novel technologies (Siegrist and Hartmann, 2020). In the case of fresh-cut products this aspect might not be negligible, when considering that freshcut vegetable products have a direct competitor in the shelf, being the non-processed counterparts. A novel disinfection technology, both chemical (e.g., ozone) or physical (e.g., ultraviolet radiation or ultrasound) in nature, might cause hesitancy or reject in food technology neophobic or suspicious consumers. In any case, it might burden the image of the fresh-cut product with a nuance of reduced naturalness when compared to the nonprocessed counterpart. To our best knowledge, no studies have been carried out until now on consumers' attitudes toward different disinfection technologies of fresh-cut produce.

\section{NEW CONCEPTUAL TOOLS FOR A COMPREHENSIVE EVALUATION OF ALL THE PROCESSING IMPACTS}

Even when future studies will have assessed the importance of cross-contamination in terms of public health and have filled the lack of information about risk assessment of all DBPs related to chlorine-based disinfection, and about the impact on the environment and food safety and quality of the alternative disinfection strategies, some other key points will remain to be addressed. First, as regards the impact of chlorine-based disinfection treatments on food safety of fresh-cut vegetables, it has been highlighted that microbiological and chemical risks tend to be influenced in an opposite way by the conditions of chlorine application. Until now, in the evaluation of these conflicting risks it has been suggested to pursue a sort of trade-off between them. However, a sound evaluation of the weight of the related risk factors has never been attempted in a formal and evidence-based way. Therefore, this seems to be a case where a ranking of the health risks that prioritize food safety risks should be established, while, to our best knowledge, no efforts to accomplish it have been done up to now in this field. Ranking of health risks related to food safety and nutrition is considered the basis for riskbased priority setting and resource allocation. In general, this allows regulatory bodies to allocate their resources efficiently to the most significant public health problems (Van Kreijl et al., 2006). Various risk ranking methodology are available and their application to prioritize food safety risks has been recently reviewed (Van der Fels-Klerx et al., 2018). The selection of the 
most appropriate method to the case of ranking hazards related to a specific food category, based on their impact on human health, will depend on the type of hazards to be ranked, i.e., microbiological or chemical, data availability, available resources and the requirements and needs of the risk manager. For instance, not all among the available methods are suitable to rank both microbiological and chemical risks. Consequently, future research should select and apply the most appropriate methodology to health risks related to fresh-cut vegetables, to achieve a consistent and comprehensive risk assessment and to guide industrial and governmental risk management actions.

A second area where the application of innovative conceptual tools could be explored relates to the need of developing holistic approaches able to pursue the different objectives of reducing the environmental impacts of the whole production process, while guaranteeing adequate food safety and quality, which can often be contradictory. When developing and evaluating alternative strategies to current disinfection treatments, how to identify the best trade-off between the different conflicting objectives? Or how to weigh their relative importance? In the field of food process engineering, several methods have been proposed to address multi-objective design problems, particularly in the last two decades, when the need of integrating sustainable development practices in the process design has been increasingly felt (Madoumier et al., 2019). These methods are grouped under the term "multi-objective optimization (MOO) methods" and include both a multi-objective processing method, when the original multi-objective problem is transformed into a solvable problem, and an optimization algorithm, which searches for trade-off solutions to the multi-objective problem. Such methods have been proposed and applied to address in a holistic perspective the four dimensions of sustainability of food engineering processes: economic sustainability and product quality and safety, which are the most evaluated dimensions, plus environmental and social sustainability. Challenges and opportunities provided by the exploitation of such methods to address multi-objective design problems in food engineering processes have been recently reviewed (Madoumier et al., 2019). Among these methods are those grouped under the term "multi-criteria decision analysis" (MCDA), or "multi-criterion decision making" (MCDM), which collectively refers to "formal approaches which seek to take explicit account of multiple criteria in helping individuals or groups explore decision that matter" (Belton and Stewart, 2002). Agri-food systems include the whole value chain and involve networks of actors and activities ranging from production to waste disposal. Therefore, a comprehensive assessment of the sustainability of agri-food systems requires the development of multi-criteria approaches based on multidisciplinary efforts (Gésan-Guiziou et al., 2020). Among these approaches, MCDA methods are designed to allow the involvement of all the stakeholders of a food supply chain, such as public authorities, governmental agencies, producers, consumers, not only in the construction of the multi-criteria evaluation but also in the subsequent decision making. In a recent review, the diversity and potentiality of MCDA methods has been emphasized for agri-food research, and it has been highlighted that they may help to move from describing or ranking systems to building evidence-based decisions that consider multiple factors and stakeholders (Gésan-Guiziou et al., 2020). The potential of application of all these methods to the optimization of the processing process and whole supply chain of fresh-cut vegetables is still to explore.

\section{LIMITATION OF SCOPE OF THE PRESENT REVIEW}

On the side of the fresh-cut produce dimension, the present review focuses only on fresh-cut vegetables and the safety aspects of these products, while only briefly discussing some specific unexplored effects on food sensory quality related to chlorine application during washing. Regarding sustainability, only environmental sustainability has been considered, whereas economic and social sustainability issues were beyond the scope of this review, even though some of the new conceptual tools here mentioned have been designed and can be used to address all the dimensions of sustainability.

\section{CONCLUSION}

The fresh-cut industry supplies the food market with products that may facilitate the consumption of healthy fresh F\&V and, in that way, contribute to the improvement of the nutritional status of the general population. However, over the last few years concerns have been raised regarding the environmental impacts of the fresh-cut industry, along with concerns about human health risks linked to the use of chlorine-based disinfectants during produce washing. Therefore, environmental and food safety issues have emerged among the key challenges the fresh-cut sector has to face. The present review attempts to provide a comprehensive view of these issues, which have been mainly related to produce washing among all the processing steps. The mainstream strategy currently applied for the washing step, based on the use of chlorine, is generally considered an effective way to manage the microbiological risk of fresh-cut produce, but its chemical food safety and environmental sustainability have been increasingly questioned. Some alternative technologies have been developed up to the commercial stage, but a clear evaluation of their advantages and downsides, in comparison to chlorine, is made troublesome by lack of experimental data. Moreover, specific challenges are posed by these environmental and food safety issues to the production of organic fresh-cut products, due to limitations in the use of chemical disinfectants and to the requirement of an efficient and responsible use of natural resources, such as water. Discussion of the most recent scientific literature on the available technologies has highlighted areas where lack of information should be filled to achieve a clearer understanding of priorities of research and actions. The interlinking nature of food safety and environmental issues has been emphasized and, accordingly, new conceptual tools, drawn from other disciplines, have been proposed to address the multiple and interrelated aspects of these issues. Even within the mentioned limitation of scope, the present review aims at stimulating a multidisciplinary approach when addressing the complex and interconnected 
issues of environmental sustainability and food safety of freshcut produce. This could take advantage from contributions from many disciplines, ranging from food technology to food safety, toxicology, human nutrition, analytical chemistry, food process engineering, environmental sciences, and others. Such a comprehensive approach could help in overcoming the hurdles that could hinder the future development of the fresh-cut sector.

\section{AUTHOR CONTRIBUTIONS}

AR and FP contributed to conception of the review, manuscript revision, read, and approved the submitted

\section{REFERENCES}

Ali, A., Yeoh, W. K., Forney, C., and Siddiqui, M. W. (2018). Advances in postharvest technologies to extend the storage life of minimally processed fruits and vegetables. Crit. Rev. Food Sci. Nutr. 58, 2632-2649. doi: 10.1080/10408398.2017.1339180

Anand, S. S., Philip, B. K., and Mehendale, H. M. (2014). "Chlorination byproducts," in Encyclopedia of Toxicology, Vol. 1, 3rd Edn, ed P. Wexler (London: Academic Press), 855-859. doi: 10.1016/B978-0-12-386454-3.00276-1

Aslam, R., Alam, M. S., and Saeed, P. A. (2020). Sanitization potential of ozone and its role in postharvest quality management of fruits and vegetables. Food Eng. Rev. 12, 48-67. doi: 10.1007/s12393-019-09204-0

Azimi, V., Munther, D., Fakoorian, S. A., Nguyen, T. T., and Simon, D. (2017). Hybrid extended Kalman filtering and noise statistics optimization for produce wash state estimation. J. Food Eng. 212, 136-145. doi: 10.1016/j.jfoodeng.2017.05.027

Banach, J., Sampers, I., Van Haute, S., and van der Fels-Klerx, H. J. (2015). Effect of disinfectants on preventing the cross-contamination of pathogens in fresh produce washing water. Int. J. Environ. Res. Public Health 12, 8658-8677. doi: 10.3390/ijerph120808658

Banach, J. L., van Bokhorst-van de Veen, H., van Overbeek, L. S., van der Zouwen, P. S., Zwietering, M. H., and van der Fels-Klerx, H. J. (2020). Effectiveness of a peracetic acid solution on Escherichia coli reduction during fresh-cut lettuce processing at the laboratory and industrial scales. Int. J. Food Microbiol. 321:108537. doi: 10.1016/j.ijfoodmicro.2020.108537

Barrett, D. M., Beaulieu, J. C., and Shewfelt, R. (2010). Color, flavor, texture, and nutritional quality of fresh-cut fruits and vegetables: desirable levels, instrumental and sensory measurement, and the effects of processing. Crit. Rev. Food Sci. Nutr. 50, 369-389. doi: 10.1080/10408391003626322

Baselice, A., Colantuoni, F., Lass, D. A., Nardone, G., and Stasi, A. (2017). Trends in EU consumers' attitude towards fresh-cut fruit and vegetables. Food Qual. Prefer. 59, 87-96. doi: 10.1016/j.foodqual.2017.01.008

Belton,. V., and Stewart, T. J. (2002). Multiple Criteria Decision Analysis: An Integrated Approach. Boston/Dordrecht/London: Kluwer Academic Publishers. doi: 10.1007/978-1-4615-1495-4_11

Bes-Rastrollo, M., Martínez-González, M. Á., Sánchez-Villegas, A., de la Fuente Arrillaga, C., and Martínez, J. A. (2006). Association of fiber intake and fruit/vegetable consumption with weight gain in a Mediterranean population. Nutrition 22, 504-511. doi: 10.1016/j.nut.2005. 12.006

Bett, K. L. (2002). "Evaluating sensory quality of fresh-cut fruits and vegetables," in Fresh-Cut Fruits and Vegetables: Science, Technology, and Market, ed O. Lamikanra (Boca Raton, FL: CRC Press), 432-443. doi: $10.1201 / 9781420031874 . c h 13$

Boeing, H., Bechthold, A., Bub, A., Ellinger, S., Haller, D., Kroke, A., et al. (2012). Critical review: vegetables and fruit in the prevention of chronic diseases. Eur. J. Nutr. 51, 637-663. doi: 10.1007/s00394-012-0380-y

Callejón, R. M., Rodríguez-Naranjo, M. I., Ubeda, C., Hornedo-Ortega, R., GarciaParrilla, M. C., and Troncoso, A. M. (2015). Reported foodborne outbreaks due version. AR wrote the first draft of the manuscript. All authors contributed to the article and approved the submitted version.

\section{ACKNOWLEDGMENTS}

The study was carried out within the frame of the ProOrg (Code of Practice for organic food processing) project. The authors acknowledge the financial support for this project provided by transnational funding bodies, being partners of the H2020 ERAnet project, CORE Organic Cofund, and the cofund from the European Commission.

to fresh produce in the United States and European Union: trends and causes. Foodb. Pathog. Dis. 12, 32-38. doi: 10.1089/fpd,.2014.1821

CBI (2021). What Trends Offer Opportunities or Pose Threats on the European Fresh Fruit and Vegetables Market? Centre for the Promotion of Imports From Developing Countries. Available online at: https://www.cbi.eu/marketinformation/fresh-fruit-vegetables/trends (accessed February 3, 2021).

CDC (2021). Reports of Selected E. coli Outbreak Investigations. Centers for Disease Control and Prevention. Available online at: https://www.cdc.gov/ ecoli/outbreaks.html (accessed February 3, 2021).

Chardon, J., Swart, A., Evers, E., and Franz, E. (2016). Public health relevance of cross-contamination in the fresh-cut vegetable industry. J. Food Protect. 79, 30-36. doi: 10.4315/0362-028X.JFP-15-272

Chen, X., and Hung, Y. (2018). Development of a chlorine dosing strategy for fresh produce washing process to maintain microbial food safety and minimize residual chlorine. J. Food Sci. 83, 1701-1706. doi: 10.1111/1750-3841.14189

Chen, X., and Hung, Y.-C. (2017). Effects of organic load, sanitizer pH and initial chlorine concentration of chlorine-based sanitizers on chlorine demand of fresh produce wash waters. Food Control 77, 96-101. doi: 10.1016/j.foodcont.2017.01.026

Coroneo, V., Carraro, V., Marras, B., Marrucci, A., Succa, S., Meloni, B., et al. (2017). Presence of Trihalomethanes in ready-to-eat vegetables disinfected with chlorine. Food Additiv. Contaminant. A 34, 2111-2117. doi: 10.1080/19440049.2017.1382723

De Ancos, B., Sánchez-Moreno, C., Plaza, L., and Cano, M. P. (2011). "Nutritional and health aspects of fresh-cut vegetables," in Advances in Fresh-Cut Fruits and Vegetables Processing, ed O. Martín-Belloso, and R. Soliva-Fortuny (Boca Raton, FL: CRC Press), 145-184. doi: 10.1201/b10263-7

Díaz-Mula, H. M., Marín, A., Jordán, M. J., and Gil, M. I. (2017). Offodor compounds responsible for quality loss of minimally processed baby spinach stored under $\mathrm{MA}$ of low $\mathrm{O}_{2}$ and high $\mathrm{CO}_{2}$ using GCMS and olfactometry techniques. Postharv. Biol. Technol. 129, 129-135. doi: 10.1016/j.postharvbio.2017.03.018

Dietrich, A. M., and Burlingame, G. A. (2020). A review: the challenge, consensus, and confusion of describing odors and tastes in drinking water. Sci. Tot. Environ. 713:135061. doi: 10.1016/j.scitotenv.2019.135061

Dryahina, K., Som, S., Smith, D., and Španěl, P. (2020). Characterization of spoilage-related volatile organic compounds in packaged leaf salads. Flav. Fragr. J. 35, 24-33. doi: 10.1002/ffj.3535

European Commission (1998). Council Directive of 3 November 1998 on the Quality of Water Intended for Human Consumption. European Council Directive 98/83/EC. Available online at: https://eur-lex.europa.eu/legalcontent/IT/ALL/?uri=CELEX\%3A31998L0083 (accessed February 3, 2021).

European Commission (2004). Regulation (EC) No 852/2004 of the European Parliament and of the Council of 29 April 2004 on the Hygiene of Foodstuffs. Available online at: https://eur-lex.europa.eu/legal-content/EN/TXT/PDF/? uri=CELEX:32004R0852\&from=EN (accessed February 3, 2021).

European Commission (2005). Commission Regulation (EC) No 2073/2005 of 15 November 2005 on Microbiological Criteria for Foodstuffs. Available online at: https://eur-lex.europa.eu/legal-content/EN/TXT/PDF/?uri=CELEX: 32005R2073\&from=EN (accessed February 3, 2021). 
European Commission (2007). Commission Regulation (EC) No 1441/2007 of 5 December 2007 Amending Regulation (EC) No 2073/2005 on Microbiological Criteria for Foodstuffs. Available online at: https://eur-lex.europa.eu/legalcontent/EN/TXT/PDF/?uri=CELEX:32007R1441\&from=EN (accessed February 3, 2021).

European Commission (2008a). Decision of 10 November 2008 Concerning the Non-inclusion of Chlorate in Annex I to Council Directive 91/414/EEC and the Withdrawal of Authorizations for Plant Protection Products Containing That Substance (2008/865/ EC). Available online at: https://eur-lex.europa.eu/ LexUriServ/LexUriServ.do?uri=OJ:L:2008:307:0007:0008:EN:PDF (accessed February 3, 2021).

European Commission (2008b). Commission Regulation (EC) No 889/2008 of 5 September 2008 Laying Down Detailed Rules for the Implementation of Council Regulation (EC) No 834/2007 on Organic Production and Labelling of Organic Products With Regard to Organic Production, Labelling and Control. Available online at: https://eur-lex.europa.eu/legal-content/EN/TXT/? uri=CELEX\%3A32008R0889 (accessed February 3, 2021).

European Commission (2019). Commission Implementing Regulation (EU) 2019/2164 of 17 December 2019 Amending Regulation (EC) No 889/2008 Laying Down Detailed Rules for the Implementation of Council Regulation (EC) No 834/2007 on Organic Production and Labelling of Organic Products With Regard to Organic Production, Labelling and Control. Available online at: https://eurlex.europa.eu/eli/reg_impl/2019/2164/oj (accessed February 3, 2021).

European Commission (2020a). Farm to Fork Strategy. For a Fair, Healthy and Environmentally-Friendly Food System. Available online at: https://ec.europa. eu/food/farm2fork_en (accessed February 3, 2021).

European Commission (2020b). Commission Regulation 2020/749 of 4 June 2020 Amending Annex III to Regulation (EC) No 396/2005 of the European Parliament and of the Council as Regards Maximum Residue Levels for Chlorate in or on Certain Products. Available online at: https://eur-lex.europa.eu/ legal-content/EN/TXT/PDF/?uri=CELEX:32020R0749\&from=EN (accessed February 3, 2021).

European Food Safety Authority (2015). 2015. Risks for public health related to the presence of chlorate in food. EFSA J. 13:103. doi: 10.2903/j.efsa.2015.4135

Fan, X., and Sokorai, K. J. (2015). Formation of trichloromethane in chlorinated water and fresh-cut produce and as a result of reaction with citric acid. Postharv. Biol. Technol. 109, 65-72. doi: 10.1016/j.postharvbio.2015.06.009

$\mathrm{FAO} / \mathrm{WHO}$ (2008). "Benefits and risks of the use of chlorine-containing disinfectants in food production and food processing," in Report of a Joint FAO/WHO Expert Meeting, Ann Arbor, MI, USA. Available online at: https:// apps.who.int/iris/handle/10665/44250 (accessed February 3, 2021).

FDA-USDA (2021a). CFR - Code of Federal Regulations Title 21, Volume 3, 21CFR173.315, Revised as of April 1, 2020. Available online at: https:// www.accessdata.fda.gov/scripts/cdrh/cfdocs/cfcfr/CFRSearch.cfm?fr=173.315 (accessed February 3, 2021).

FDA-USDA (2021b). CFR - Code of Federal Regulations Title 21, Volume 3, 21CFR173.368, Revised as of April 1, 2020. Available online at: https:// www.accessdata.fda.gov/scripts/cdrh/cfdocs/cfcfr/cfrsearch.cfm?fr=173.368 (accessed February 3, 2021).

Franz, E. (2018). "Quantifying human health risks associated with microbiological contamination of fresh vegetables," in Quantitative Methods for Food Safety and Quality in the Vegetable Industry, eds F. Pérez-Rodríguez, P. Skandamis, and V. Valdramidis (Cham: Springer International Publishing), 161-173. doi: 10.1007/978-3-319-68177-1_7

Freshfel (2021). 2020 Consumption Monitor. (European Fresh produce Association). Available online at: https://freshfel.org/what-we-do/consumption-monitor/ (accessed February 3, 2021).

Froder, H., Geraldes Martins, C., de Souza, K. L. O., Landgraf, M., Franco, B. D. G. M., and Destro, M. T. (2007). Minimally processed vegetable salads: microbial quality evaluation. J. Food Protect. 70, 1277-1280. doi: $10.4315 / 0362-028 X-70.5 .1277$

Fu, T.-J., Li, Y., Awad, D., Zhou, T.-Y., and Liu, L. (2018). Factors affecting the performance and monitoring of a chlorine wash in preventing Escherichia coli O157:H7 cross-contamination during postharvest washing of cut lettuce. Food Control 94, 212-221. doi: 10.1016/j.foodcont.2018.06.035

Fusi, A., Castellani, V., Bacenetti, J., Cocetta, G., Fiala, M., and Guidetti, R. (2016). The environmental impact of the production of fresh cut salad: a case study in Italy. Int. J. Life Cycle Assess. 21, 162-175. doi: 10.1007/s11367-015-1019-z
Garrido, Y., Marín, A., Tudela, J. A., Allende, A., and Gil, M. I. (2019). Chlorate uptake during washing is influenced by product type and cut piece size, as well as washing time and wash water content. Postharv. Biol. Technol. 151, 45-52. doi: 10.1016/j.postharvbio.2019.01.014

Gésan-Guiziou, G., Alaphilippe, A., Aubin, J., Bockstaller, C., Boutrou, R., Buche, P., et al. (2020). Diversity and potentiality of multi-criteria decision analysis methods for agri-food research. Agron. Sustain. Dev. 40:44. doi: 10.1007/s13593-020-00650-3

Gil, M. I., and Allende, A. (2018). "Water and wastewater use in the fresh produce industry: food safety and environmental implications," in Quantitative Methods for Food Safety and Quality in the Vegetable Industry. Food Microbiology and Food Safety, eds F. Pérez-Rodríguez, P. Skandamis, and V. Valdramidis (Cham: Springer), 59-76. doi: 10.1007/978-3-319-68177-1_4

Gil, M. I., Allende, A., and Selma, M. V. (2011). "Treatments to assure safety of fresh-cut fruits and vegetables," in Advances in Fresh-Cut Fruits and Vegetables Processing, eds O. Martín-Belloso, and R. Soliva-Fortuny (Boca Raton, FL: CRC Press), 211-230. doi: 10.1201/b10263-9

Gil, M. I., Allende, A., and Selma, M. V. (2012). "Minimal processing" in Decontamination of Fresh and Minimally Processed Produce, ed V. M. Gómez-López (Oxford, UK: John Wiley \& Sons), 105-120. doi: $10.1002 / 9781118229187 . c h 6$

Gil, M. I., Gómez-López, V. M., Hung, Y.-C., and Allende, A. (2015). Potential of electrolyzed water as an alternative disinfectant agent in the fresh-cut industry. Food Bioprocess Technol. 8, 1336-1348. doi: 10.1007/s11947-014-1444-1

Gil, M. I., and Kader, A. A. (2008). "Fresh-cut fruit and vegetables," in Improving the Health-Promoting Properties of Fruit and Vegetable Products, eds F. A. Tomás-Barberán and M. I. Gil (Boca Raton, FL: CRC Press), 475-504. doi: 10.1533/9781845694289.5.475

Gil, M. I., López-Gálvez, F., Andújar, S., Moreno, M., and Allende, A. (2019). Disinfection by-products generated by sodium hypochlorite and electrochemical disinfection in different process wash water and fresh-cut products and their reduction by activated carbon. Food Control 100, 46-52. doi: 10.1016/j.foodcont.2018.12.050

Gil, M. I., Marín, A., Andujar, S., and Allende, A. (2016). Should chlorate residues be of concern in fresh-cut salads? Food Control 60, 416-421. doi: $10.1016 /$ j.foodcont.2015.08.023

Gómez-López, V. M., Marín, A., Medina-Martínez, M. S., Gil, M. I., and Allende, A. (2013). Generation of trihalomethanes with chlorine-based sanitizers and impact on microbial, nutritional and sensory quality of baby spinach. Postharv. Biol. Technol. 85, 210-217. doi: 10.1016/j.postharvbio.2013.05.012

Goodburn, C., and Wallace, C. A. (2013). The microbiological efficacy of decontamination methodologies for fresh produce: a review. Food Control 32, 418-427. doi: 10.1016/j.foodcont.2012.12.012

Holvoet, K., Jacxsens, L., Sampers, I., and Uyttendaele, M. (2012). Insight into the prevalence and distribution of microbial contamination to evaluate water management in the fresh produce processing industry. J. Food Protect. 75, 671-681. doi: 10.4315/0362-028X.JFP-11-175

Hurst, W. C. (2002). "Safety aspects of fresh-cut fruits and vegetables," in Fresh-Cut Fruits and Vegetables: Science, Technology, and Market, ed O. Lamikanra (Boca Raton, FL: CRC Press), 54-99. doi: 10.1201/9781420031874.ch,4

IFOAM-Organics International (2018). The IFOAM NORMS for Organic Production and Processing Version 2014. Available online at: https://www. ifoam.bio/sites/default/files/2020-09/norms_2014_OUTDATED.pdf (accessed February 3, 2021).

IZSVe (2015). Linsalata confezionata e pronta al consumo è sicura? L'efficacia dei metodi di lavaggio domestici $e$ industriali. Istituto Zooprofilattico Sperimentale delle Venezie. Available online at: https://www.izsvenezie.it/ insalata-confezionata-pronta-al-consumo-sicura/ (accessed February 3, 2021).

Lee, W.-N., and Huang, C.-H. (2019). Formation of disinfection byproducts in wash water and lettuce by washing with sodium hypochlorite and peracetic acid sanitizers. Food Chem. 1:100003. doi: 10.1016/j.fochx.2018.100003

Lee, W.-N., Huang, C.-H., and Zhu, G. (2019). Analytical methods for conventional and emerging disinfection by-products in fresh-cut produce. Food Chem. 291, 30-37. doi: 10.1016/j.foodchem.2019.03.150

López-Gálvez, F., Tudela, J. A., Allende, A., and Gil, M. I. (2019). Microbial and chemical characterization of commercial washing lines of fresh produce highlights the need for process water control. Innov. Food Sci. Emerg. Technol. 51, 211-219. doi: 10.1016/j.ifset.2018.05.002 
Luo, Y. (2007). Fresh-cut produce washwater reuse affects water quality and packaged product quality and microbial growth in romaine lettuce. HortScience 42, 1413-1419. doi: 10.21273/HORTSCI.42.6.1413

Luo, Y., Zhou, B., Van Haute, S., Nou, X., Zhang, B., Teng, Z., et al. (2018). Association between bacterial survival and free chlorine concentration during commercial fresh-cut produce wash operation. Food Microbiol. 70, 120-128. doi: 10.1016/j.fm.2017.09.013

Madoumier, M., Trystram, G., Sébastian, P., and Collignan, A. (2019). Towards a holistic approach for multi-objective optimization of food processes: a critical review. Trends Food Sci. Technol. 86, 1-15. doi: 10.1016/j.tifs.2019.02.002

Maffei, D. F., Sant'Ana, A. S., Franco, B. D. G. M., and Schaffner, D. W. (2017). Quantitative assessment of the impact of cross-contamination during the washing step of ready-to-eat leafy greens on the risk of illness caused by Salmonella. Food Res. Int. 92, 106-112. doi: 10.1016/j.foodres.2016.12.014

Manzocco, L., Ignat, A., Anese, M., Bot, F., Calligaris, S., Valoppi, F., et al. (2015). Efficient management of the water resource in the fresh-cut industry: current status and perspectives. Trends Food Sci. Technol. 46, 286-294. doi: 10.1016/j.tifs.2015.09.003

Marín, A., Tudela, J. A., Garrido, Y., Albolafio, S., Hernández, N., Andújar, S., et al. (2020). Chlorinated wash water and $\mathrm{pH}$ regulators affect chlorine gas emission and disinfection by-products. Innov. Food Sci. Emerg. Technol. 66:102533, doi: 10.1016/j.ifset.2020.102533

Meireles, A., Giaouris, E., and Simões, M. (2016). Alternative disinfection methods to chlorine for use in the fresh-cut industry. Food Res. Int. 82, 71-85. doi: 10.1016/j.foodres.2016.01.021

Moravicki, R. O. (2012). "Water and wastewater," in Sustainability for the Food Sciences, ed R. O. Moravicki (Oxford: Wiley-Blackwell), 189-226. doi: 10.1002/9780470963166.ch 9

Nahim-Granados, S., Rivas-Ibáñez, G., Antonio Sánchez Pérez, J., Oller, I., Malato, S., and Polo-López, M. I. (2020). Synthetic fresh-cut wastewater disinfection and decontamination by ozonation at pilot scale. Water Res. 170:115304. doi: 10.1016/j.watres.2019.115304

Ölmez, H. (2012). "Ozone," in Decontamination of Fresh and Minimally Processed Produce, ed V. M. Gómez-López (Oxford: Wiley-Blackwell), 177-196. doi: $10.1002 / 9781118229187 . \operatorname{ch} 10$

Ölmez, H. (2017). "Environmental impacts of minimally processed refrigerated fruits and vegetables' industry," in Minimally Processed Refrigerated Fruits and Vegetables. 2nd Edn, eds F. Yildiz and R. C. Wiley (New York, NY: Springer), 747-756. doi: 10.1007/978-1-4939-7018-6_22

Ölmez, H., and Kretzschmar, U. (2009). Potential alternative disinfection methods for organic fresh-cut industry for minimizing water consumption and environmental impact. LWT 42, 686-693. doi: 10.1016/j.lwt.2008.08.001

Paulikiene, S., Venslauskas, K., Raila, A., Žvirdauskiene, R., and Naujokiene, V. (2020). The influence of ozone technology on reduction of carrot loss and environmental IMPACT. J. Clean. Prod. 244:118734. doi: 10.1016/j.jclepro.2019.118734

Raffo, A., Moneta, E., Ferrari Nicoli, S., and Paoletti, F. (2020). GC-olfactometric characterisation of off-odours in commercially packaged rocket leaves. Food Packag. Shelf Life 25:100540. doi: 10.1016/j.fpsl.2020.100540

Raffo, A., Senatore, M., Moneta, E., Paoletti, F., Peparaio, M., and Saggia Civitelli, E. (2021). Impact of different temperature abuse scenarios on sensory quality and off-odour formation in ready-to-eat salad leaves. Int. J. Food Sci. Technol. 56, 2345-2356. doi: 10.1111/ijfs.14858

Ramos, B., Miller, F. A., Brandão, T. R. S., Teixeira, P., and Silva, C. L. M. (2013). Fresh fruits and vegetables-an overview on applied methodologies to improve its quality and safety. Innov. Food Sci. Emerg. Technol. 20, 1-15. doi: 10.1016/j.ifset.2013.07.002

Richardson, S. D., and Postigo, C. (2012). "Drinking water disinfection byproducts," in Emerging Organic Contaminants and Human Health, ed D. Barceló (Berlin: Springer-Verlag), 93-137. doi: 10.1007/698_2011_125

Rojas-Graü, M. A., Garner, E., and Martín-Belloso, O. (2011). "The freshcut fruit and vegetables industry: current situation and market trends," in Advances in Fresh-Cut Fruits and Vegetables Processing, eds O. Martín-Belloso and R. Soliva-Fortuny (Boca Raton, FL: CRC Press), 1-12. doi: 10.1201/b10 263-2

Sant'Anna, P. B., Melo Franco, B. D., and Maffei, D. F. (2020). Microbiological safety of ready-to-eat minimally processed vegetables in Brazil: an overview. J. Sci. Food Agri. 100, 4664-4670. doi: 10.1002/jsfa.10438
Siegrist, M., and Hartmann, C. (2020). Consumer acceptance of novel food technologies. Nat. Food 1, 343-350. doi: 10.1038/s43016-020-0094-x

Srinivasan, P., Dehghan Abnavi, M., Sulak, A., Kothapalli, C. R., and Munther, D. (2020). Towards enhanced chlorine control: mathematical modeling for free chlorine kinetics during fresh-cut carrot, cabbage and lettuce washing. Postharv. Biol. Technol. 161:111092. doi: 10.1016/j.postharvbio.2019.111092

SUSCLEAN (2015). Code of Best Practices for Cleaning and Disinfection of Minimally Processed Vegetables /2014/, Sustainable Cleaning and Disinfection in Fresh-Cut Food Industries- EU FP7 Project. Available online at: https://cordis. europa.eu/programme/id/FP7_KBBE.2011.2.3-01 (accessed February 3, 2021).

The Nordic Council (2012). Nordic Nutrition Recommendations 2012. Available online at: https://www.norden.org/en/publication/nordic-nutritionrecommendations-2012 (accessed February 3, 2021).

Tudela, J. A., López-Gálvez, F., Allende, A., and Gil, M. I. (2019a). Chlorination management in commercial fresh produce processing lines. Food Control 106:106760. doi: 10.1016/j.foodcont.2019.106760

Tudela, J. A., López-Gálvez, F., Allende, A., Hernández, N., Andújar, S., Marín, A., et al. (2019b). Operational limits of sodium hypochlorite for different fresh produce wash water based on microbial inactivation and disinfection by-products (DBPs). Food Control 104, 300-307. doi: 10.1016/j.foodcont.2019.05.005

USEPA (2006). National Primary Drinking Water Regulations: Stage 2 Disinfectants and Disinfection Byproducts Rule, Federal Register 71, No. 2, 387-493. Washington, DC: United States Environmental Protection Agency, Office of Water. Available online at: https://www.federalregister.gov/documents/ 2006/01/04/06-3/national-primary-drinking-water-regulations-stage-2disinfectants-and-disinfection-byproducts-rule (accessed February 3, 2021).

Van den Berg, M. (2019). An introduction to the market for organic processed food in Europe. Workshop "Organic processing in Europe. Quo vadis?" Nurnberg: Biofach.

Van der Fels-Klerx, H. J., Van Asselt, E. D., Raley, M., Poulsen, M., Korsgaard, H., Bredsdorff, L., et al. (2018). Critical review of methods for risk ranking of food-related hazards, based on risks for human health. Crit. Rev. Food Sci. Nutr. 58, 178-193. doi: 10.1080/10408398.2016.11 41165

Van Haute, S., Luo, Y., Sampers, I., Mei, L., Teng, Z., Zhou, B., et al. (2018). Can UV absorbance rapidly estimate the chlorine demand in wash water during fresh-cut produce washing processes? Postharv. Biol. Technol. 142, 19-27. doi: 10.1016/j.postharvbio.2018.02.002

Van Haute, S., Zhou, B., Luo, Y., Sampers, I., Vanhaverbeke, M., and Millner, P. (2019). The use of redox potential to estimate free chlorine in fresh produce washing operations: possibilities and limitations. Postharv. Biol. Technol. 156:110957. doi: 10.1016/j.postharvbio.2019.110957

Van Kreijl, C. F., Knaap, A. G. A. C., and Van Raiij, J. M. A. (2006). Our Food, our Health - Healthy Diet and Safe Foods in the Netherlands (in Dutch). Report 270555009. Bilthoven: Institute of Public Health and the Environment (RIVM), 364

Vigil, M., Pedrosa Laza, M., Moran-Palacios, H., and Alvarez Cabal, J. (2020). Optimizing the environmental profile of fresh-cut produce: life cycle assessment of novel decontamination and sanitation techniques. Sustainability 12:3674. doi: 10.3390/su12093674

Wang, J., Wang, S., Sun, Y., Li, C., Li, Y., Zhang, Q., et al. (2019). Reduction of Escherichia coli O157:H7 and naturally present microbes on fresh-cut lettuce using lactic acid and aqueous ozone. RSC Adv. 9:22636. doi: 10.1039/C9RA0 $3544 \mathrm{C}$

Weng, S., Luo, Y., Li, J., Zhou, B., Jacangelo, J. G., and Schwab, K. J. (2016). Assessment and speciation of chlorine demand in fresh-cut produce wash water. Food Control 60, 543-551. doi: 10.1016/j.foodcont.2015. 08.031

Willett, W., Rockström, J., Loken, B., Springmann, M., Lang, T., Vermeulen, S., et al. (2019). Food in the Anthropocene: the EAT-Lancet Commission on healthy diets from sustainable food systems. Lancet 393, 447-492. doi: 10.1016/S0140-6736(18)3 $1788-4$

World Health Organization (2017). Guidelines for Drinking-Water Quality: Fourth Edition Incorporating the First Addendum. Geneva. Available online at: https:// apps.who.int/iris/bitstream/handle/10665/44584/9789241548151_eng.pdf? sequence $=1$ (accessed February 3, 2021). 
World Health Organization (2020). Healthy Diet (Updated 29 April 2020). Available online at: https://www.who.int/news-room/fact-sheets/detail/ healthy-diet (accessed February 3, 2021).

Conflict of Interest: The authors declare that the research was conducted in the absence of any commercial or financial relationships that could be construed as a potential conflict of interest.

Publisher's Note: All claims expressed in this article are solely those of the authors and do not necessarily represent those of their affiliated organizations, or those of the publisher, the editors and the reviewers. Any product that may be evaluated in this article, or claim that may be made by its manufacturer, is not guaranteed or endorsed by the publisher.

Copyright (๑) 2022 Raffo and Paoletti. This is an open-access article distributed under the terms of the Creative Commons Attribution License (CC BY). The use, distribution or reproduction in other forums is permitted, provided the original author(s) and the copyright owner(s) are credited and that the original publication in this journal is cited, in accordance with accepted academic practice. No use, distribution or reproduction is permitted which does not comply with these terms. 